\title{
Facebook'ta Bulunma Amacı ve Facebook Reklamlarına Duyulan İlgi Arasındaki İlişki
}

\author{
The Relationship Between Purpose of Using Facebook and \\ Interest with Facebook Ads
}

\section{Prof. Dr. Ömer Torlak - Arş. Grv. Ufuk Ay}

\begin{abstract}
Öz
Bu araștırmada Facebook'ta bulunma amaçları ile Facebook reklamlarına duyulan ilgi arasında bir ilişki olup olmadiğı ölçülmüsştür. Bu amaçla internet üzerinden 283 kişiye anket uygulanmıştır. Araştırmanın bulguları Facebook'ta bulunma amaçları olarak tanımlanan "sosyal arama" ve "sosyal tarama" değişkenleriyle Facebook reklamlarina duyulan ilgi arasinda anlaml ilişkiler olduğunu destekler niteliktedir.
\end{abstract}

Anahtar Kelimeler: Sosyal Medya Reklamcılığı, Facebook Reklamları, Sosyal A $\breve{g}$ Siteleri

\begin{abstract}
This study aims to determine whether or not there is a relationship between interest with Facebook ads and purpose of using Facebook. The survey was applied to 283 people on internet for this purpose. The findings of research confirm relationship between interest with Facebook ads and "social searching" and "social browsing" defining as purposes of using Facebook.
\end{abstract}

Keywords: Social Media Advertising, Facebook Ads, Social Networking Sites

\section{Giriş}

Her geçen gün yaygın ve yoğun kullanıma açık hale gelen internetin, kullanıcılar tarafından farklı amaçlarla kullanıldığ bilgiye ulaşma, iletişim kurma, sosyal paylaşım ve alışveriş gibi farklı amaçlarla kullanılan internete erişim ülkemizde de artmakta ve yaygınlaşmaktadır. 2012 Nisan ayı istatistiklerine göre Türkiye'de internete erişim imkânı olan hane oranı $\% 47,2$ 'ye yükselmiştir. İnternet kullanıcıların \%61,3’ü interneti mal ve hizmetler hakkında bilgi aramak için kullanmaktadır. İnternet kullanan bireylerin internet üzerinden kişisel kullanım amacıyla mal veya hizmet sipariş verme ya da satın alma oran $\% 21,8$ 'dir. Yani internet kullanan 5 kişiden biri internet üzerinden alışveriş yapmaktadır (TÜİK, erişim tarihi: 26.02.2013).

İnternet mesafe sınırını ortadan kaldırmak suretiyle ve yüz yüze iletişim olmaksızın kullanıcıları arasındaki paylaşım ve sosyal iletişime firsat vermektedir. İnternetin bu özelliklerini kullanıp, iletişim dalı içinde kendine özgün bir yer açma başarısı gösteren alanlardan biri ise sosyal medyadır. Kaplan ve Haenlein (2010) sosyal medyayı "kullanıcı tarafından oluşturulan içeriğin yaratımı ve değişimine ve Web 2.0'ın ideolojik ve teknik temellerine dayanan internet temelli uygulamalar grubu" olarak tanımlamaktadır. Kaplan ve Haenlein (2010) sosyal medyayı işbirliğine dayalı projeler, bloglar, içerik toplulukları, sanal oyun dünyaları, sanal sosyal dünyalar ve sosyal ağ siteleri olarak belli sınıflara ayırmışlardır. Bu kapsamda sosyal medyanın bir parçası olan bireylerin ve doğal olarak tüketicilerin internette en fazla rağbet gösterdiği siteler sosyal ağ siteleridir. Sosyal ağ siteleri kişilere, sınırlı bir sistem içerisinde halka açı yahut halka yarı açık profiller oluşturma, bağlantılı oldukları diğer kullanıcıların bir listesini sergileme ve sistem içindeki arkadaşlarının ve diğer kullanıcıların listelerini görüntüleme imkânı veren Web tabanlı bir hizmet olarak tanımlanabilir (Boyd ve Ellison: 211). Sosyal

Prof. Dr. Ömer Torlak, KTO Karatay Üniversitesi İIBF, omer.torlak@karatay.edu.tr Arş. Grv. Ufuk Ay, KTO Karatay Üniversitesi İİBF, ufuk.ay@karatay.edu.tr 
ağ siteleri bir başka tanıma göre ise, kullanıcıları çoğunlukla bir fotoğrafın; isim, ikamet edilen yer, yaş, meslek, cinsiyet gibi temel istatistiklerin bir listesinin ve hobiler, favori kitaplar, TV programları vb. şeylerden oluşan ilgi alanlarının biçimlendirdiği bir profil sayfası oluşturmaya teşvik eden web hizmetleridir (Golder vd., 2007).

Sosyal ağ siteleri kullanıcılarına büyük bir çeşitlilik içeren teknik özellikler sağlamasına rağmen, bu sitelerin belkemiğini aynı zamanda sistemin kullanıcıları olan arkadaşların bir listesini gösteren görüntülenebilen profiller oluşturmaktadır. ${ }^{1}$ Profiller bir bireyin kendisini olmak istediği şekilde ifade edebileceği kişiye özgü sayfalardır (Sunden'den aktaran Boyd ve Ellison, 2008). Sosyal medya aynı zamanda kullanıcı tarafından diğer kullanıcıları (ya da tüketicileri) pazaryerinde var olan ürünler, hizmetler ve markalar hakkında bilgilendirmek amacıyla oluşturulan, kullanılan ve belirli bir döngü içerisinde tekrarlanan çoklu çevrimiçi bilgi kaynaklarını içerir (Murugesan, 2007).

Sosyal ağ siteleri içerisinde kamuoyu tarafından en çok bilineni ve reklam mecrası olarak da en fazla kullanılanı kuşkusuz Facebook'tur. Facebook 2004 yılında kurulmuştur. İlk kurulduğunda yalnızca Harvard Üniversitesi öğrencilerine açık olacak şekilde dizayn edilen site katılım için "harvard.edu" uzantılı mail adreslerini zorunlu kılan bir yapıda olan site 2005 y1lında site mevcut ağını lise öğrencilerini, şirketleri ve nihayetinde herkesi kapsayacak bir biçimde genişletmiştir (Boyd ve Ellison, 2008).

Pek çok sosyal network sitesinde olduğu gibi, Facebook da kullanıcılarına kişisel bilgiler ve arkadaş listelerini içeren profil sayfalarını kişiselleştirme fırsatı verir. Kullanıcılar arkadaş listelerinde olsun veya olmasın diğer kullanıcılara mesaj atma şansına sahiptir. ${ }^{2}$

1 Sosyal ağ sitelerinde arkadaş kavramı, fan, takipçi, bağlantı gibi farklı şekillerde de ifade edilebilir. Bu kavramı arkadaşlı̆ıın normal tanımıyla karıştırmamak gerekir. Sosyal ağ sitelerindeki arkadaşlıkların çevrimdışı bir bağlantı ile sürdürülmesi yahut gerçek dünyada bir karşılığının olması gerekmez. Bireyler çevrimdışı ortamda bir ilişki kurmaksızın ortak fikirler, ilgiler, faaliyetler vb. açılardan sosyal ağ sitelerinde arkadaşlık kurabilirler.

2 Sosyal ağ sitelerinde arkadaș kavramı, fan, takipçi, bağlantı gibi farklı şekillerde de ifade edilebilir. Bu kavramı arkadaşlığın normal tanımıyla karıştırmamak gerekir. Sosyal ağ sitelerindeki arkadaşlıkların çevrimdışı bir bağlantı ile sürdürülmesi yahut gerçek dünyada bir karşıllı̆ının olması gerekmez. Bireyler çevrimdışı ortamda bir ilişki kurmaksızın ortak fikirler, ilgiler, faaliyetler vb. açılardan sosyal ağ sitelerinde arkadaşlık kurabilirler.
Kullanıcı ayrıca herhangi bir sosyal gruba katılabilir, diğer kullanıcıları "arkadaş" olarak ekleyebilir, fotoğraf paylaşabilir bir kişinin "duvarına" kişiye özel olmayan diğer kullanıcılara açık mesajlar yazabilir. Facebook'ta diğer sitelerden farklı olarak "dürtme" (poke) olarak adlandırılan herhangi bir içeriği olmayan mesajlar da atılabilir (Golder vd., 2007).

Facebook'un 2012 yılında açıkladığı istatistiklere göre üye sayısı 900 milyona ulaşmıştır (ntvmsnbc, Erişim. Tarihi 17.04.2013). Facebook ve genel olarak sosyal ağ siteleri müşterileriyle temasta kalmak ve onlardan geri bildirim almak bakımından şirketler için güçlü bir araç olarak görülmektedir. Şirketler ayrıca müşterileriyle Facebook dahilinde açllan fan grupları vasıtasıyla da kontak kurabilirler (Vejacka, 2013:116). İstatistiklere göre Facebook'ta en fazla fanı olan marka Coca-Cola'dır. Bu markanın Facebook dahilinde yaklaşık 63 milyon fanı bulunmaktadır (socialbakers, Erişim Tarihi: 17.04.2013)

Whiting ve Williams (2013) bireyleri sosyal medyay1 kullanmaya iten 10 farklı kullanım ve tatmin alanı belirlemişlerdir. $\mathrm{Bu}$ alanlar; sosyal etkileşim, bilgi arayışı, zaman geçirme, eğlence, rahatlama, iletişimsel fayda, kullanım kolaylığı, fikirleri ifade etme, bilgi paylaşımı ve başkaları hakkında bilgi sahibi olma alanlarıdır. Lampe vd. (2006) ise üniversite öğrencileri arasındaki Facebook kullanımı ile ilgili yaptıkları çalışmada iki temel kullanım belirlemişlerdir. Bu kullanımlar sosyal arama ve sosyal taramadır. Sosyal arama olarak adlandırılan kullanım; bazı bireylerin Facebook'ta çevrimdışı bağlantılarını sanal ortama yani çevrimiçine taşıma çabalarını nitelerken, sosyal tarama ise bazı bireyler sanal ortamdan yeni bağlantılar kurup bunu dış dünyaya yani çevrimdışı ortama taşıma gayretlerini vurgular (Lampe vd. :168). Facebook'ta bu iki farklı amaçla bulunan bireylerin birer tüketici olarak bu sosyal ağda yayınlanan çok sayıda reklama maruz kaldıkları da bilinmektedir. İki farklı amaçla sosyal ağda bulunan tüketicilerin bu sosyal ağdaki reklamlara yönelik algılarının farklı olup olmadıklarının bilinmesi hem literatür hem de uygulamacılar açısından önemli hale gelmektedir. Başka bir deyişle, facebook sosyal ağında sosyal arama ve sosyal tarama amaçları ile bulunan tüketicilerin facebook reklamlarına ilgileri arasında farklılık olup olmadığı sorusunun cevabı önemli hale gelmektedir. $\mathrm{Bu}$ soruya bulunacak cevap kapsamında, facebook reklamlarına duyulan ilginin düzeyi ve uygulamacıların bu mecradaki reklamlarda farklı amaçlara yönelik 
kullanıcılara yönelik nelere dikkat etmeleri gerektiği konularında ipuçları elde edilebilir.

$\mathrm{Bu}$ açıdan araştırmanın cevap aradığı temel soru; "Facebook'ta bulunma amacı ile Facebook reklamlarına duyulan ilgi arasında bir ilişki var mıdır" şeklinde oluşturulmuştur. Yapılan literatür taraması kapsamında gerek yerli gerekse yabancı yazında böyle bir çalışmaya rastlanmaması bu araştırmayı önemli kılmaktadır.

\section{İlgili Literatür}

$\mathrm{Bu}$ bölümde çalışmanın temel yapısını oluşturan, Facebook'ta bulunma amaçları olarak tanımlanan sosyal arama, sosyal tarama hakkkında ve Faceboook reklamları hakkında ayrıntılı bilgiler verilecek ve konuyla ilgili literatür genel olarak tanıtılmaya çalışılacaktır.

Tüketicilerin genel olarak sosyal medyayı nasıl kullandıkları ve ondan ne beklediklerini bilmek önemlidir. Bu bağlamda temellerini iletişim yazınından alan kullanım ve doyum teorisi (uses and gratifications theory) sosyal medya pazarlamacılarının daha iyi ölçekler geliştirmesi için tamamlayıcı bir parça olarak görülebilir. (Whiting veWilliams, 2013:362) Bu teorinin temel savı; bireylerin, onların ihtiyaçlarını karşılayan ve nihai doyum sağlayan medya arayışında olduklarıdır (Laricy vd., 2011). Bu teori doğrultusunda Whiting ve Williams (2013); sosyal etkileşim, bilgi arayışı, zaman geçirme, eğlence, rahatlama, iletişimsel fayda, kullanım kolaylığı, fikirleri ifade etme, bilgi paylaşımı ve başkalarını gözetleme/başkaları hakkında bilgi sahibi olma gibi bireyleri sosyal medyayı kullanmaya iten 10 farklı kullanım ve tatmin alanı belirlemişlerdir. Lampe vd. (2006)'nin facebook kullanımları olarak tanımladığı sosyal arama ve sosyal tarama kavramı özellikle "başkalarını gözetleme (surveillance) "şeklinde kavramsallaştırılan sosyal medya kullanımı ile ilişkilidir. Bu aşamada Lampe vd. (2006)'nin tanımladığı sosyal arama (social searching) ve sosyal tarama (social browsing) kavramlarından, bireyin/ tüketicinin facebook'u kullanmasındaki temel gayesine referansda bulunduğu için "Facebook'ta Bulunma Amaçları” șeklinde bahsedilecektir.

\section{Facebook'ta Bulunma Amaçları}

Facebook gibi sosyal ağ sitelerinin de işlevlerinden olan "gözetleme (surveillance) fonksiyonu bireylere ait oldukları daha geniş toplulukların inançları- nı, ilgilerini ve hareketlerini takip etme şansı verir" (Shoemaker,1996). Bu açıdan çevrimdışı bir bağlantı paylaştığı kişiler hakkında daha fazla bilgi edinmek için onları sanal ortama yani çevrimiçine taşımak olarak tanımlanabilecek "sosyal arama" ve kendine yakın gördüğü yahut içinde bulunmayı arzu ettiği topluluklarla veya kişilerle sanal ortamdan bağlantı kurup bunu diş dünyaya yani çevrimdışı ortama taşımak şeklinde tanımlanabilecek "sosyal tarama" gibi Facebook kullanma amaçları aslında kullanım ve doyum teorisinin tanımladığı alanlardan "başkalarını gözetleme/başkaları hakkında bilgi sahibi olma” ile ilişkilidir.

Arkadaş listesi oluşturma bütün sosyal network sitelerinin önemli bir özelliği olduğundan doğal olarak arkadaş arama faaliyetleri bu sitelerin kullanıcılarının sitede bulunma amaçlarının başında yer alır. Kişinin halihazırda gerçek hayatta tanıdığı insanlarla sosyal network sitelerinde de ilişki kurması yani sosyal arama aslına bakılırsa site yapıcıları tarafından da kişinin gerçek hayatta tanımadığı bir insanla site aracılığıyla bağlantı kurmak istemesi anlamına gelen sosyal tarama faaliyetlerine yeğ tutulur. Çünkü sosyal tarama faaliyetleri bazen özellikle kadın kullanıcıların taciz edilmesi gibi istenmeyen durumlara ve güvenlik ile ilgili endişelere sebebiyet verebilir. Nitekim Facebook'un hem sosyal aramayı hem de sosyal taramayı mümkün kılan bir site olmakla beraber kişilerin tanımadıkları kullanıcılara mesaj göndermelerini paralı hale getirme gibi uygulamalarla sosyal tarama imkanını kısıtlamaya çalıştı̆̆ı söylenebilir. Ayrıca yapilan pek çok araştırmada da bireylerin sosyal arama faaliyetleri ile sosyal tarama faaliyetlerine göre daha çok ilgili olduğu ortaya çıkmaktadır (Golder vd., 2007; Ellison vd., 2007; Vasalou vd., 2010).

\section{Facebook Reklamları}

Sosyal medya siteleri firmalar için başka mecralarda kolay kolay bulamayacakları firsatlar sunar. Bu firsatlar arasında bu sitelerin firma ve müşteriler arasındaki etkileşimi arttırması, reklamın hedef kitlesinin daha kolay bir biçimde belirlenebilmesi ve bu sitelerin müşterilerin birbirleriyle ve potansiyel müşterilerle iletişim kurmasına olanak veren yapısı bulunmaktadır (Roberts, 2010:26).

Ürün ve markalarla ilgili reklam mesajlarının yayılı$\mathrm{m}$ geleneksel veya modern uygun iletişim mecraları seçilerek yapılır. Facebook, özellikle modern iletişim mecralarından biri olarak değerlendirilen internet 
ağı içinde kullanıcıları geniş bir coğrafi alana yayıldığ 1 için reklam verenler açısından oldukça popüler bir sosyal ağ sitesidir (Yousif, 2012: 122).

Facebook'un kullacıların yaşadıkları ülke ve şehir, yaş, cinsiyet, meslek, ilgi alanları vb. kişisel faktörler bazında oldukça büyük bir çeşitlilik göstermesi daha önce de belirtildiği gibi ilgili reklamın hedef kitlesini bulma ve daha geniş bir bakış açısıyla baktığımız takdirde pazar bölümlendirmesi yapma açısından reklam veren firmalara büyük kolaylıklar sağlar. Ayrıca yapılan pek çok araştırmada kişisel ve demografik faktörlerin tüketicinin sosyal medya reklamlarını algılama biçiminde önemli farklılıklara neden olduğu ortaya konulmuştur. (Taylor vd., 2011; Lukka ve James, 2014).

Facebook, kullanıcı sayısının fazlalığının yanı sıra gençler arasındaki popülerliğinden dolayı da pazarlamacılar için çekici bir hale gelmiştir (Logan vd., 2012:166). 2009 boyunca ABD’nin en hizlı gelişen 500 firmasının yüzde 43 'ü sosyal ağ sitelerinin pazarlama stratejileri için çok önemli olduğunu, yüzde 68’i ise ürünlerini ve markalarını sosyal medya alanında sergilediklerini belirtmişlerdir. (Barnes ve Mattson, 2009). Bu durum en bilinen sosyal ağ sitelerinden biri olan Facebook'ta yer alan reklamlar ve tüketicilerin bu reklamları nasıl algıladığı ile ilgili yapılan pek çok akademik çalışmaya zemin hazırlamıştır. Taylor vd. (2011) tüketicilerin sosyal medya reklamlarını kabullenme düzeyinin bu reklamların sağladığı bilgi ve eğlence düzeyinden etkilendiğini ortaya koymuştur. Brehm (1996) ise tüketicilerin sosyal medya reklamlarını öfkelendirici, saldırgan ve aldatıcı bulduklarında ikna olmaya daha az yatkın olduklarını saptamıştır. Kişilerin Facebook kullanma amaçları bu bağlamda
Facebook reklamlarına karşı takındıkları tavırda etkili olabilir. Bu sebeble aşağıdaki hipotezler geliştirilmiştir.

H1: Sosyal arama ile Facebook reklamlarına duyulan ilgi arasında anlamlı bir ilişki vardır.

H1a: Sosyal arama ile reklamların içeriği arasında anlamlı bir ilişki vardır.

H1b: Sosyal arama ile Facebook reklamlarina duyulan güven ve inanç arasında anlamlı bir ilişki vardir.

H1c: Sosyal arama ile satın alma ve motivasyon arasında anlamlı bir ilişki vardır.

H1d: Sosyal arama ile Facebook reklamlariyla ilgilenme arasında anlamlı bir ilişki vardır.

H2: Sosyal tarama ile Facebook reklamlarına duyulan ilgi arasında anlamlı bir ilişki vardır

H2a: Sosyal tarama ile reklamların içeriği arasında anlamlı bir ilişki vardır.

H2b: Sosyal tarama ile Facebook reklamlarina duyulan güven ve inanç arasında anlamlı bir ilişki vardir.

H2c: Sosyal tarama ile satın alma ve motivasyon arasında anlamlı bir ilişki vardır.

H2d: Sosyal tarama ile Facebook reklamlaryla ilgilenme arasında anlamlı bir ilișki vardır.

\section{Araştırmanın Yöntemi}

Bu bölümde araştırmanın modeli, hipotezleri, evren ve örneklemi, örnekleme ve veri toplama yöntemi, bulguları ve analizleri hakkında bilgi verilecektir.

\section{Araștırmanın Modeli}

Facebook reklamlarına duyulan ilgi düzeyi
Facebook'ta bulunma amaçları

Şekil 1. Araştırma Modeli

\section{Evren ve Örneklem}

Araştırmanın evreni facebook kullanıcılarıdır. Evrenin güncel listesine erişim imkanı hemen hemen imkansız olduğundan, kolayda örnekleme yoluyla internet aracilığ ile ulaşılan toplam 283 kişiden veri toplanmıştır. İlgili anket formu Facebook'ta ve çeşitli forumlarda o an çevrimiçi olan kişilere uygulanmıştır. Veri toplama işlemi 1 Mart ve 24 Nisan 2013 tarihleri arasında gerçekleştirilmiş ve toplanan veriler SPSS 18.0 istatistik programında analiz edilmiştir. 


\section{Ölçekler ve Güvenilirlik Katsayıları}

Araştırmada iki farklı ölçek kullanılmıştır. Bunlardan Facebook'ta bulunma amaçlarını ölçen ölçek Vasolou vd. (2010)'dan alınmış olup toplam 11 ifadeden oluşmaktadır. Çalışmada kullanılan bu ölçeğin Cronbach-Alfa katsayısı 0,74 olup güvenilirlik düzeyi kabul edilebilir bir değerdedir. Facebook reklamlarına olan ilgiyi ölçen ölçek ise Yousif (2012)'den alınmış olup toplam 13 ifadeden oluşmaktadır. Cronbach-alfa katsayısı 0,94 olup güvenilirlik düzeyi gayet makuldur. Toplanan veriler "(5) kesinlikle katılıyorum... (1) kesinlikle katılmıyorum” şeklindeki likert ölçeği ile sayısallaştırılmıştır.

\section{Bulgular ve Analiz}

Bu bölümde araştırma kapsamındaki bireylerin gerek kişisel gerekse Facebook sitesini kullanma alıșkanlıkları ile ilgili bilgiler verilecek, bireylerin Facebook'ta bulunma amacı ve Facebook reklamlarına gösterdikleri ilgi analiz edilecektir.

\section{Cevaplayıcıların Kişisel Özellikleri ve Facebook Kullanma Alışkanlıkları}

Tablo 1'den de anlaşılacı̆̆ı üzere cevaplayıcıların çoğunluğunu \%52,7’lik bir oranla kadınlar oluştururken cevaplayıcıların çoğu \%44,5’lık bir oranla 23-27 yaş aralığında olan bireylerdir. Ayrıca cevaplayıcıla-

Tablo 1. Cevaplayıcıların Özellikleri

\begin{tabular}{|c|c|c|}
\hline Değişken & Frekans & Yüzde \\
\hline \multicolumn{3}{|l|}{ Cinsiyet } \\
\hline Erkek & 133 & 47,0 \\
\hline Kadın & 149 & 52,7 \\
\hline Belirtmeyen & 1 & 0,3 \\
\hline \multicolumn{3}{|l|}{ Yaş } \\
\hline 22 ve alt 1 & 102 & 36,1 \\
\hline $23-27$ & 126 & 44,5 \\
\hline $27-30$ & 19 & 6,7 \\
\hline 30 üstü & 30 & 10,6 \\
\hline Belirtmeyen & 6 & 2,1 \\
\hline \multicolumn{3}{|l|}{ Facebook'a giriş sıklığı } \\
\hline Günde birden fazla & 203 & 71,7 \\
\hline Günde bir defa & 47 & 16,6 \\
\hline Haftada bir veya birkaç defa & 22 & 7,8 \\
\hline Belirtmeyen & 11 & 3,9 \\
\hline
\end{tabular}


rın \%71,7'si Facebook’a günde bir dafadan fazla giriş yaptığını belirtmiştir. Bütün bunlara ek olarak cevaplayıcıların Facebook'taki arkadaş sayısı ortalama 376'dır. Bu kişiler günde ortalama 2 saat 40 dakika Facebook'ta vakit geçirmektedirler.

\section{Facebook Kullanma Amaçları ve Facebook \\ Reklamlarına Gösterilen IIIgi Düzeyi ile ilgili ifade Ortalamaları}

Tablo 2'deki 11 ifadeden ilk 6'sı sosyal arama kalan 5 'i ise sosyal tarama ifadeleridir. Tablo 2'den de anlaşlacağı gibi cevaplayıcılar sosyal aramaya, sosyal taramaya göre görünür bir biçimde daha fazla önem atfetmektedirler. Sonraki ifadeler ise Facebook reklam- larına duyulan ilgi düzeyini ölçmektedir. Yine tablodaki değerlerden anlaşılacığı üzere cevaplayıcıların Facebook reklamlarına gösterdikleri ilgi kesinlikle katılmıyorum ve katılmıyorum ibareleri etrafinda toplanmıştır. Bu durumda cevaplayıcıların reklamlara gösterdikleri ilginin düşük olduğu söylenebilir.

\section{Ölçeklerin Faktör Yapıları}

Tablo 3'den de anlaşılacağı üzere ölçek sosyal arama ve sosyal tarama olarak iki farklı boyuta ayrılmaktadır. Bu iki faktör tüm yapının 0,51'lik kısmını açıklamaktadır. Uygunluk test sonuçlarına göre ölçek faktör analizine uygundur ve analiz istatistiki açıdan anlamlidir.

Tablo 2. Ifade Ortalamaları

\begin{tabular}{|c|c|c|}
\hline İfade & Ort. & St.Sap. \\
\hline Facebook’u eski arkadaşlarımın şu an ne yaptığını öğrenmek için kullanıyorum & 3,08 & 1,02 \\
\hline $\begin{array}{l}\text { Facebook'u irtibatımı kaybettiğim kişilerle tekrar bağlantıya geçmek için } \\
\text { kullanıyorum }\end{array}$ & 3,32 & 0,99 \\
\hline $\begin{array}{l}\text { Facebook'u sıklıkla görüşme imkanı bulamadığım kişilerle bağlantımı sürdürmek } \\
\text { için kullanıyorum }\end{array}$ & 3,44 & 1,06 \\
\hline $\begin{array}{l}\text { Facebook aracılığıyla görüşmediğim takdirde irtibatımı kaybedebileceğim kişilerle } \\
\text { bağlantımı sürdürmek için Facebook'u kullanıyorum }\end{array}$ & 3,00 & 1,09 \\
\hline Facebook’u bir süredir görmediğim insanları bulmak için kullanıyorum & 3,15 & 1,01 \\
\hline Facebook'u yurt dışındaki arkadaşlarla bağlantı kurmak için kullanıyorum & 2,93 & 1,25 \\
\hline Facebook'u diğer insanların arkadaşlarını görmek için kullanıyorum & 2,14 & 0,99 \\
\hline Facebook'u tanımadığım insanların profiline bakmak için kullanıyorum & 1,98 & 1,02 \\
\hline Facebook'u arkadaşlarımın arkadaşlarına göz atmak için kullanıyorum & 2,04 & 0,96 \\
\hline Facebook'u yeni insanlarla tanışmak için kullanıyorum & 2,07 & 1,08 \\
\hline $\begin{array}{l}\text { Facebook'u belirli insanları bulmak amacıyla gelişmiş arama yapmak için } \\
\text { kullanıyorum }\end{array}$ & 2,07 & 1,00 \\
\hline Facebook aracılığıyla reklam mesajları alıyorum & 2,78 & 1,28 \\
\hline
\end{tabular}

"(5) Kesinlikle kat1lyorum. ..(1) Kesinlikle katılmıyorum 


\section{Tablo 2. Ifade Ortalamaları (Devamı)}

\begin{tabular}{|l|c|c|}
\hline Facebook aracılığıyla gelen reklam mesajlarıyla ilgileniyorum & 1,84 & 0,95 \\
\hline $\begin{array}{l}\text { Facebook aracılığıyla gelen reklam mesajları ürün hakkında önemli bir bilgi kaynağı } \\
\text { sunar }\end{array}$ & 2,16 & 1,04 \\
\hline Facebook aracılığıyla gelen reklam mesajlarının içeriği heyecan verici ve çekicidir. & 1,91 & 0,96 \\
\hline Facebook aracılığyla gelen reklam mesajlarının içeriği ikna edicidir. & 1,91 & 0,94 \\
\hline $\begin{array}{l}\text { Facebook aracılığıyla gelen reklam mesajları beni içeriği hakkında arkadaşlarımla } \\
\text { tartışmaya yönlendirir. }\end{array}$ & 1,84 & 0,88 \\
\hline $\begin{array}{l}\text { Facebook aracılığıyla gelen reklam mesajları reklamı yapılan ürünleri satın almak } \\
\text { için beni motive eder. }\end{array}$ & 1,81 & 0,86 \\
\hline $\begin{array}{l}\text { Arkadaşlarımı Facebook aracılığıyla reklamı yapılan ürünleri satın alması için teşvik } \\
\text { ederim. }\end{array}$ & 1,64 & 0,82 \\
\hline Facebook aracılığıyla gönderilen bilgiler sebebiyle ürün satın aldım. & 1,59 & 0,86 \\
\hline $\begin{array}{l}\text { Facebook aracıllığıyla gelen reklam mesajları reklamı yapılan ürünleri tanımak } \\
\text { amacıyla ilgili firmanın web sitesine girmem için beni motive eder. }\end{array}$ & 2,12 & 1,10 \\
\hline Facebook aracılığıyla gelen reklam mesajları güvenilirdir. \\
\hline $\begin{array}{l}\text { Facebordiği bilgi güvenilirdir. } \\
\text { Fçin başarılı bir medya aracı olduğuna inanıyorum. }\end{array}$
\end{tabular}

Tablo 3. Facebook'ta Bulunma Amaçları

\begin{tabular}{|l|c|c|}
\hline Faktör ve İfadeler & $\begin{array}{l}\text { Faktör } \\
\text { Yükü }\end{array}$ & $\begin{array}{l}\text { Açıladığı } \\
\text { Varyans \% si }\end{array}$ \\
\hline Sosyal Arama & $\mathbf{2 5 , 8}$ \\
\hline $\begin{array}{l}\text { Facebook'u irtibatı kaybettiğim kişilerle tekrar bağlantıya geçmek için } \\
\text { kullanıyorum }\end{array}$ & 0,76 & 0,72 \\
\hline $\begin{array}{l}\text { Facebook'u sıklıkla görüşme imkânı bulamadığım kişilerle bağlantımı } \\
\text { sürdürmek için kullanıyorum }\end{array}$ & 0,69 & \\
\hline Facebook'u bir süredir görmediğim insanları bulmak için kullanıyorum & 0,66 & \\
\hline $\begin{array}{l}\text { Facebook'u görüşmediğim taktirde bağlantımın kesilebileceği kişilerle } \\
\text { bağlantı kurmak için kullanıyorum }\end{array}$ & 0,64 & \\
\hline $\begin{array}{l}\text { Facebook'u eski arkadaşlarımın şu an ne yaptığını öğrenmek için } \\
\text { kullanıyorum }\end{array}$ & 0,55 & \\
\hline $\begin{array}{l}\text { Facebook'u yurt dışındaki arkadaşlarımla bağlantı kurmak için } \\
\text { kullanıyorum. }\end{array}$ & & \\
\hline
\end{tabular}


Tablo 3. Facebook'ta Bulunma Amaçları (Devamı)

\begin{tabular}{|l|c|c|}
\hline Sosyal Tarama & $\mathbf{2 5 , 2 9}$ \\
\hline Facebook'u tanımadığım insanların profiline bakmak için kullanıyorum & 0,85 & \\
\hline Facebook'u arkadaşlarımın arkadaşlarına göz atmak için kullanıyorum. & 0,82 & \\
\hline Facebook'u diğer insanların arkadaşlarını görmek için kullanıyorum & 0,72 & \\
\hline Facebook'u yeni insanlarla tanışmak için kullanıyorum. & 0,63 & \\
\hline $\begin{array}{l}\text { Facebook'u belirli özellikteki insanları bulmak amacıyla gelişmiş arama } \\
\text { yapmak için kullanıyorum. }\end{array}$ & 0,58 & \\
\hline Açılanan toplam Varyans & & $\mathbf{5 1 , 0 9}$ \\
\hline Barlets Küresellik Testi: Ki Kare:870, SD:55, Sig:0,00, KMO 0,79 & \\
\hline
\end{tabular}

\section{Tablo 4. Facebook Reklamlarına Olan Illgi}

\begin{tabular}{|c|c|c|}
\hline Faktör ve İfadeler & $\begin{array}{l}\text { Faktör } \\
\text { Yükü }\end{array}$ & $\begin{array}{l}\text { Açıkladığı } \\
\text { Varyans \% si }\end{array}$ \\
\hline Reklamların İçeriği & & $\mathbf{2 4 , 8}$ \\
\hline Facebook aracılığıyla gelen reklam mesajlarının içeriği ikna edicidir. & 0,80 & \\
\hline $\begin{array}{l}\text { Facebook aracılığıyla gelen reklam mesajlarının içeriği çekici ve heyecan } \\
\text { vericidir. }\end{array}$ & 0,79 & \\
\hline $\begin{array}{l}\text { Facebook aracılığıyla gelen reklam mesajları, reklamı yapılan ürün } \\
\text { hakkında önemli bir bilgi kaynağı sunar. }\end{array}$ & 0,66 & \\
\hline $\begin{array}{l}\text { Facebook aracılığıyla gelen reklam mesajları beni, içeriği hakkında } \\
\text { arkadaşlarımla tartışmaya yönlendirir }\end{array}$ & 0,65 & \\
\hline Facebook aracılığıyla gelen reklam mesajlarıyla ilgileniyorum & 0,51 & \\
\hline Facebook'a duyulan güven ve inanç & & 23,7 \\
\hline Facebook aracılığıyla gelen reklam mesajları güvenilirdir. & 0,84 & \\
\hline $\begin{array}{l}\text { Facebook aracılığıyla ürün veya firma hakkında gönderilen reklam } \\
\text { mesajlarının içerdiği bilgi güvenilirdir. }\end{array}$ & 0,82 & \\
\hline $\begin{array}{l}\text { Facebook aracılığıyla gönderilen reklam mesajlarının çeşitli ürünlerin } \\
\text { promosyonu için başarılı bir medya aracı olduğuna inanıyorum. }\end{array}$ & 0,68 & \\
\hline $\begin{array}{l}\text { Facebook aracılığıyla gelen reklam mesajları reklamı yapılan ürünleri } \\
\text { tanımak amacıyla ilgili firmanın web sitesine girmem için beni motive } \\
\text { eder. }\end{array}$ & 0,54 & \\
\hline
\end{tabular}


Tablo 4. Facebook Reklamlarına Olan IIgi (Devamı)

\begin{tabular}{|l|c|c|}
\hline Satın Alma ve Motivasyon & $\mathbf{2 1 , 8}$ \\
\hline $\begin{array}{l}\text { Arkadaşlarımı Facebook aracılı̆̆ıyla reklamı yapılan ürünleri satın alması } \\
\text { için teşvik ederim. }\end{array}$ & 0,79 & \\
\hline Facebook aracılığıyla gönderilen bilgiler sebebiyle ürün satın aldım. & 0,77 & \\
\hline $\begin{array}{l}\text { Facebook aracıllğıyla gelen reklam mesajları reklamı yapılan ürünleri } \\
\text { satın almak için beni motive eder }\end{array}$ & 0,68 & $\mathbf{8 , 8}$ \\
\hline Facebook Reklamlarıyla İlgilenme & & \\
\hline Facebook aracıllığıyla reklam mesajları alıyorum & 0,96 & $\mathbf{7 9 , 1 7}$ \\
\hline Açıklanan toplam Varyans & & \\
\hline Barlets Küresellik Testi: Ki Kare:2804, SD:78, Sig:0,00,KMO: $\mathbf{0 , 9 2}$ & & \\
\hline
\end{tabular}

Facebook reklamlarına duyulan ilgiyi ölçen soru seti 5 ayrı faktör altında toplanmış olup bu faktörler tüm yapının 0,79 'unu açıklamaktadır. Uygunluk test so- nuçlarına göre soru seti faktör analizine tabi tutulmak için oldukça uygun bir yapıdadır ve analiz istatistiki açıdan da anlamlıdır.

Tablo 5. Facebook'ta Bulunma Amaçları ve Facebook Reklamlarına Duyulan İgi Arasındaki Korelasyonlar

\begin{tabular}{|l|l|l|l|l|l|l|}
\hline & Sosyal & Sosyal \\
Arama & Tarama & Reklamları & Güvenirlikve siteye & Satın Alma ve & İlgilenme \\
inanç & Motivasyon & \\
\hline Sosyal Arama & & 0,001 & $-0,094$ & $-0,024$ & $-0,06$ & $0,216^{*}$ \\
\hline Sosyal Tarama & & & $0,164^{* *}$ & $-0,032$ & $0,341^{* *}$ & 0,086 \\
\hline
\end{tabular}

${ }^{* *} \mathrm{p}<0,01{ }^{*} \mathrm{p}<0,05$

\section{Değişkenler Arası ilişskiler}

Tablo 5'den de anlaşılacağ 1 üzere Facebook'ta bulunma amaçlarından "sosyal arama" boyutu Facebook reklamlarına duyulan ilgi değişkeninin "Facebook reklamlarıla ilgilenme" boyutuyla zayıf fakat pozitif bir ilişki halindedir. Amaç değișkeninin diğer boyutu "Sosyal Tarama" reklamların içeriği boyutuyla zayıf fakat pozitif bir ilişki halindeyken, satın alma ve motivasyon boyutuyla aralarında orta şiddette bir ilişki mevcuttur. Bu durumda sosyal tarama amacı güdenlerin reklam mesajlarıyla hem içeriği açısından hem de satın alma motivasyonu açısından daha ilgili oldu- ğu söylenebilir. Böylece "H1d: Sosyal arama ile Facebook reklamlarıyla ilgilenme arasinda anlamlı bir ilişki vardır.", "H2a: Sosyal tarama ile reklamların içeriği arasında anlamlı bir ilişki vardır" ve "H2c: Sosyal tarama ile satın alma ve motivasyon arasinda anlamlı bir ilişki vardır" hipotezleri desteklenmiştir. Buna göre "H1: Sosyal arama ile Facebook reklamlarına duyulan ilgi arasında anlamlı bir ilişki vardır" ve "H2: Sosyal tarama ile Facebook reklamlarına duyulan ilgi arasında anlamlı bir ilişsi vardır" hipotezleri kısmen desteklenmiştir. 


\section{Sonuç, Tartışma ve Öneriler}

Sosyal aramayı ölçen ifadelere yaklaşık olarak 3 (ne katılıyorum ne katılmıorum) civarında bir katılım gerçekleşmiştir. Sosyal tarama ifadelerinde ise bu durum 2 (katılmıyorum) civarındadır. Yani bireyler dış dünyadaki bağlantılarını sanal aleme taşımayı, sanal alemden bağlantılar kurup bunu gerçek dünyaya taşımaya yeğlemişlerdir. Bu durumun genel olarak litaratürle uyumlu olduğu söylenebilir (Lampe vd.,2006; Golder vd.,2007; Ellison vd.,2007; Vasalou vd., 2010). Sonuç olarak böyle bir bulgu bizi sosyal ağ sitelerinde bulunan bireylerin çevrimiçi ağlarını oluştururken reel arkadaş veya tanıdık çevrelerinden yararlandıkları sonucuna ulaştırabilir.

Facebook reklamlarına gösterilen ilgi düzeyi söz konusu olduğunda ise cevaplayıcıların Facebook reklamlarına olan ilgisinin çok düşük bir düzeyde gerçekleştiği ortaya çıkmaktadır. Bu düzey yaklaşık 2 (katılmıyorum) civarındadır. Bu durum literatür ile biraz ters düşmektedir. Örneğin Yousif (2012)'de facebook reklamlarına duyulan ilgi ortalama 3,50 civarındadır. Bu durumun sebebi genel olarak internet ortamına karşı ve daha özel bir perspektifde ise bazı olumsuz deneyimler sonucu internetten alışveriş gibi olgulara karşı geliştirilmiş olan ve etkisini hala yer yer sürdüren ön yargılar olabilir. Örneğin Logan vd. (2012) kadın tüketicilerin sosyal medyaya karşı duyduğu rahatsızlığın, sosyal medya reklamlarına verdikleri değeri azalttığını ortaya koymuştur. Brehm (1996) ise tüketicilerin sosyal medya reklamlarını öfkelendirici, saldırgan ve aldatıcı bulduklarında ikna olmaya daha az yatkın olduklarını saptamıştır. Bu bağlamda tüketicinin sosyal medya reklamlarına karş1 gösterdiği düşük ilginin sebebinin, sosyal medyadan duyulan rahatsızlık olabileceği söylenebilir.

Sosyal tarama boyutuyla, "reklamların içeriği" ve satın alma ve motivasyon" boyutları arasındaki pozitif ilişki gayet anlamlıdır. Bu ilişki bize, Facebook üzerinden çeşitli insanlarla bağlantılar kurup bunu gerçek dünyaya taşıma gayreti içinde olan insanların facebook reklamlarının içeriğiyle daha ilgili olduklarını söyler. Nitekim bu insanlar Facebook dahilinde sürekli bir arayış içinde olduklarından böyle reklamlarla sosyal tarama eğiliminde olmayan tüketicilere göre daha sık karşılaşırlar. Bu bağlamda özellikle bireyin de sürece dahil olabileceği etkileşim düzeyi yüksek reklamlar vasitasıyla bu niteliğe sahip tüketicilerle daha olumlu ilişkiler kurulabilir. Nitekim Muntinga vd. (2011)'nin yaptığı bir çalışmada tüketicilerin sosyal ağ sitelerinde marka ile ilgili faaliyetlerle meşgul oldukça ilgili markaya yaptıkları katkı (marka topluluklarının forumlarındaki tartışmalara katılma vb.) düzeyinin arttığı ortaya çıkmıştır. Ayrıca sosyal tarama amacı güden bireylerin "satın alma ve motivasyon" değişkeniyle ilişkisi reklamların içeriği değişkeniyle ilişkisine oranla daha üst bir seviyede gerçekleştiğinden, bu kişiler, yani sosyal tarama yapanlar, reklamlardan daha fazla etkilenip gerekli motivasyonu sağlayarak satın alma kararını sosyal arama ile meşgul olan kişilere göre daha hızlı verebilirler. $\mathrm{Bu}$ durum Facebook'ta sosyal arama amacinda olan insanların, yani var olan ilişki ağlarını sanal ağlarına dahil etme arzusunda olan kişilerin, facebook reklamlarıyla ilgili sadece reklamlardan haberdar olma durumunu kapsayan reklamlarla ilgilenme boyutuyla pozitif bir ilişki içinde olmalarını da açıklamaktadır.

Pazarlama uygulamacıları ve sosyal medya reklamcıları için sunulan öneriler özetlenecek olursan şunlar söylenebilir. Yapılan araştırmalara göre firmaların sosyal medyada yer alma eğilimi oldukça yüksek seviyelerde gerçekleşirken (Barnes ve Mattson, 2009) aynı zamanda ortalama 5 kullanıcıdan yalnızca 1'i facebook reklamlarından etkilenmek suretiyle ürün veya hizmet satın aldığını ifade etmektedir (Oreskoviç'den aktaran Beauchamp, 2013). Fakat tüketicinin de Facebook reklamlarına karşı bakıç açısı tam anlamıla net değildir. Nitekim Cohen (2012)' e göre tüketicilerin $\% 64$ 'ü sosyal medya profillerinde reklam mesajı görmekten nefret ederken $\% 54$ 'ü firmaların Facebook veya diğer sosyal ağ sitelerinde sayfaları olmasını takdir etmektedir. Bu durumda sosyal medya reklamcılarına düşen, sosyal ağlarda yayınlanan reklamların tüketicinin de sürece dahil olabileceği etkileşim düzeyi yüksek (Muntinga vd., 2011) ve hem eğlendirici hem bilgilendirici (Logan vd.,2012) niteliklere sahip şekilde tasarlanmasını sağlamaktır. Ayrıca sosyal ağ sitelerinde pazarlama iletişimi faaliyetleri yürüten markalar, bu siteler içinde sürekli bir arayış durumunda olan ve sanal ortamdan yeni tanışıklıklar oluşturup (bunun amacı normalde kabul edilmeme olasılığı bulunan sosyal bir gruba sa- 
nal ortamda dahil olmak, flört etmek vb. olabilir) bu ilişkileri gerçek dünyada sağlamlaştırma amacında olan bireylerin yani sosyal tarayıcıların, sosyal aray1cılara göre reklamlardan daha fazla etkilenme ve satın alma motivasyonu sağlama olasılığına sahip olduklarını daima akıllarında tutmalıdırlar.

Gelecek araştırmalar ve araştırmacılar içinse iki temel öneri sunulabilir. Birincisi, araştırmacılar Facebook reklamlarının neden kuşkuyla karşılandığını yahut gerçekten kuşkuyla karşılanıp karşılanmadığını sebepleriyle ortaya koyabilirler. İkinci öneri ise herhangi bir marka özelinde, bu markanın sempatizanlarının oluşturdukları sanal topluluklarda, ilgili marka hakkında topluluk üyelerinin duygu ve düşüncelerini ortaya çıkarmaya yönelik yapılabilecek bir çalışmadır. Bu muhtemel çalışma için Robert Kozinets’in geliştirdiği netrografi tekniğinden yararlanılabilir.

\section{Kaynakça}

Barnes, N. G., ve Mattson, E. (2009). Social Media in the 2009 Inc 500: new tools and new trends. Journal of New Communucation Research, 4(2).

Beauchamp, M. B. (2013). Don't Invade My Personal Space: Facebook's Advertising Dilemma. The Journal of Applied Business Research, 29(1), 91-96.

Boyd, D. M., ve Ellison, N. B. (2008). Social Network Sites: Definition,History, Scholarship. Journal of Computer-Mediated Communacition(13), 210-230.

Brehm, J. W. (1966). A theory of Psychological Reactance. New York: Academic Press.

Cohen, D. (2012). Brands, maintain a facebook page, but don't bother me, http://allfacebook.com/facebook-page-consumers_b78793. (Erişim Tarihi: 20.08.2014)

Delozier, M. W. (1976). The Marketing Communucation Process. New York: MCGraw-Hill Book.

Elden, M. (2003). Reklamcılığın Yeni Yüzü: İnternet Reklamcılı̆̆ı. İstanbul Üniversitesi İletişim Fakültesi Dergisi, 18(1), 247-278.
Golder, S. A., Wilkinson, D. M., Huberman, B. A. (2007). Rhythms of Social Interaction: Messaging Within a Massive Online Network. Communities and Technologies 2007, 41-66.

Greenberg, B. S., ve Brand, J. E. (1993). Television news and advertising in schools: The "Channel One" contoversy. Journal of Communication, 43(1), 143151.

Kaplan, A. M., ve Haenlin, M. (2010). Users of the world, unite! The challenges and oppurtunites of social media. Business Horizon, 53(1), 59-68.

Lampe, C., Ellison, N., Steinfield, C. (2006). A Facebook in the Crowd: Social Searching vs. Social Browsing. Proceedins of the 2006 20th anniversary conference on Computer supporter cooperative work (pp. 167-170). New York: ACM Press.

Laricy, R. W., Tinkham, S. F., Sweetser, K. D. (2011). Kids these days: examining differences in political uses and gratifications, internet political participation,political information efficacy,and cynicism on the basis of age. American Behavioral Scientist, 55(6), 749-764.

Logan, K., Bright, L., Gangadharbatla, H. (2012). Facebook versus television: advertisin value pereptions among females. Journal of Research in Interactive Marketing, 6(3), 164-179.

Lukka, V., ve James, P. T. (2014). Attitudes toward Facebook advertising. Journal of management and Marketing Research, 1, 1-26.

Murugesan, S. (2007). Understanding Web 2.0. IT Professional, 9(4), 34-41.

Odabaşı, Y., ve Oyman, M. (2005). Pazarlama İletişimi Yönetimi (9. Baskı ed.). İstanbul: MediaCat.

Roberts, K. K. (2010). Privacy and Perceptions: How Facebook Advertising Affects its Users. The Elon Journal of Undergraduate Research in Communications, 1(1), 24-34.

Shomaker, P. J. (1996). Using biological and cultural evolution to explain the surveillance function. Journal of Communication, 46(3).

Sunden, J. (2003). Material Virtualities. New York: Peter Lang. 
Taylor, D. G., Lewin, J. E., Strutton, D. (2011). Friends, Fans and Followers: Do ads Work on Social Networks? How gender and Agge Shape Receptivity. Journal of Advertising Research, 1, 258-275.

TÜİK. (2012). Hanehalkı Bilişim Teknolojileri Kullanım Araştırması 2012. http://www.tuik.gov.tr/ PreHaberBultenleri.do?id=10880 (Erişim tarihi: 26.02.2013)

Varnalı, K. (2012). Dijital Kabilelerin İzinde. İstanbul: Kapital Medya Hizmetleri.

Vasalou, A., Joinson, A. N., Courvoisier, D. (2010). Cultural Diffrence, Experience with Social Networks and The Nature of "true commitment"in Facebook. İternational Journal of Human-Computer Studies, 719-728.
Vejacka, M. (2013). Facebook Advertising and Its Efficiency on the Slovak Market. Economy and Management, 1(1), 116-126.

Whiting, A., ve Williams, D. (2013). Why people use social media: a uses and gratifications approach. Qualitative Market Research: An International Journal, 16(4), 362-369.

Yousif, R. O. (2012). The Extent of Facebook Users' Interest in the Advertising Messages. International Journal of Marketing Studies, 4(3), 122-133.

http://www.ntvmsnbc.com/id/25342821/ (Erişim Tarihi: 17.04.2013)

http://www.socialbakers.com/facebook-pages/brands/ (Erişim Tarihi: 17.04.2013) 